\title{
Effect of Ractopamine on Lipid Metabolism in vivo - a Systematic Review
}

\author{
Matheus Soares da Silva Ferreira ${ }^{*}$, Cesar Augusto Pospissil Garbossa ${ }^{2}$, Guilherme \\ Oberlender $^{2}$, Luciano José Pereira ${ }^{1}$, Márcio Gilberto Zangeronimo ${ }^{1}$, Raimundo Vicente de \\ Sousa $^{1}$ and Vinícius de Souza Cantarelli ${ }^{2}$ \\ ${ }^{1}$ Departamento de Medicina Veterinária; Universidade Federal de Lavras; Lavras - MG - Brasil. ${ }^{2}$ Deparatamento \\ de Zootecnia; Universidade Federal de Lavras; Lavras - MG - Brasil
}

\begin{abstract}
The aim of this article was to evaluate the in vivo mechanism of action through which ractopamine reduces the amount of adipose tissue in carcass of animals fed diets supplemented with this drug. Literature search was carried out, using the keywords Ractopamine, lipogenesis, lipolysis, fatty acid and adipose tissue. The scoring system was designed for the adequacy of the methodology. A total of eight papers were found - all published in the English language. The determination of lipolysis and lipogenesis was carried out using different methods - from the quantification of non-esterified fatty acids in the blood to molecular analyses of adipose tissue. The review analysis suggested that, at least in the pigs, the use of this drug reduced lipid deposition in the carcass due to a greater inhibition of lipogenesis than an increase in lipolysis.
\end{abstract}

Key words: $\beta$-adrenergic agonist, Lipogenesis, Lipolysis

\section{INTRODUCTION}

In the global context of the increase in human populations and the demand for food as well as the scarcity of large areas for livestock farming and the need to preserve environmental resources (Hejnfelt and Angelidaki 2009; Petersen 2010), the use of substances that increase the efficiency of animal production and the use of dietary nutrients may be viable alternatives for the modern world (Ferreira et al. 2011). The $\beta$-adrenergic agonist (BAA) pharmaceutical class has been widely used for the modification of carcass in some species of animals in different countries. Among this class of drugs, ractopamine is a synthetic $\beta$-agonist with proven efficiency in the production of meat with a lower fat content and greater utilization of nutrients from the diets (Mitchell et al. 2009;
Gonzales et al. 2010). BAAs act through specific metabolic pathways, especially in the metabolism of proteins, lipids and carbohydrates, redirecting nutrients from the diet to metabolic pathways that favor protein synthesis over the deposition of fat in the carcass (Gunawan et al. 2007; Carr et al. 2009).

A reduction in the deposition of adipose tissue in the carcass of pigs fed the diets containing ractopamine has been reported by many authors (Uttaro et al. 1993; See et al. 2004; Mimbs et al. 2005). Apparently, this effect occurs through two metabolic pathways: reduction in lipogenesis and/or increase in lipolysis. Analyzing the adipocytes isolated from pigs fed the diets containing ractopamine, Liu et al. (1989) determined the lipolytic rate of these cells through the formation of glycerol and found that the

\footnotetext{
*Author for correspondence: mfmv433@ gmail.com
} 
reduction in adipose tissue in the carcass occurred through an increase in lipolysis. On the other hand, Mills and Liu (1990) and Peterla and Scanes (1990) worked with swine adipocytes in vitro measuring the rate of lipogenesis through the incorporation of glucose labeled with carbon 14 in fatty acids and found that a reduction in lipogenesis was the key reaction in this process. Moreover, adipocytes isolated from SpragueDawley rats stimulated by ractopamine have been found to exhibit both an increase in lipolysis and efficient inhibition of lipogenesis with equal potency (Hausmann et al. 1989). Kim et al. (2010) studied the effects of clenbuterol, which was a similar BAA, using a triglyceride cytoplasmic marker and found a discreet reduction in lipogenesis, but an accentuated increase in lipolysis.

Considering the lack of consensus in the literature regarding the mechanisms responsible for the effects of ractopamine on the metabolism of lipids, a systematic review was considered as necessary for the selection of studies with a high level of scientific evidence for the clarification of this impasse. The understanding of the events of lipolysis and/or lipogenesis stemming from supplementation with ractopamine could help in determining the correct balance of feed ingredients for the optimization of the effects of supplementation.

The aim of the present review was to evaluate the mechanism of action through which ractopamine reduced the amount of adipose tissue deposited in the carcass of animals, which were fed with the diets supplemented with this additive.

\section{MATERIALS AND METHODS}

Electronic searches were carried out in November 2010 in the PubMed (http://www.ncbi.nlm.nih.gov/pubmed), Scopus (http://www.scopus.com), ISI Web of Science (http://apps.isiknowledge.com) and Science Direct (http://www.sciencedirect.com) databases, using the following keywords Ractopamine, lipogenesis, lipolysis, fatty acid and adipose tissue. The word Ractopamine was combined one-to-one with all other terms, accompanied by the article and the following combinations were also used: Ractopamine and lipogenesis and lipolysis; Ractopamine and lipogenesis and lipolysis and fatty acid; Ractopamine and lipogenesis and fatty acid; Ractopamine and lipolysis and fatty acid. Additional papers and texts addressing the use of ractopamine and its effects on the metabolism of adipose tissue were also cited and used in when appropriate.

The present review was related to in vivo trials that evaluated the activity of ractopamine as a promoter of a reduction in the fat content in the carcass of any species of animal. Scientific papers that employed any method for the quantification of lipolysis and/or lipogenesis were selected. The search was limited to scientific papers published in peer-reviewed journals indexed in the aforementioned databases, with no limitations regarding the year and date of publication. No restrictions were made with regard to the language in which the paper was published, provided that the Abstract was available in English.

The definition of papers for inclusion was performed during a consensus meeting among the researchers, taking into consideration the statistical design, quality of the methodology, and types of analysis and quantification of the results. The data were displayed in the tables and compared based on the criteria described below.

The randomization parameters (random allocation of each animal to a particular treatment), blind evaluation (evaluator unaware of the substance provided to the animal or to which treatment each animal was submitted) and use of a control group were classified based on the following scale: adequate (2), unclear (1) and inadequate (0). The sample size $(n)$ criterion was established based on the number of animals employed for the measurement of the variable studied, using the following scale: more than 20 animals (3), from 11 to 20 animals (2) and 0 to 10 animals (1).

For each study analyzed, the quality of the method employed for the determination of lipolysis and lipogenesis was assessed with regard to whether the study only quantified one of these variables (score: 1) or both variables (score: 2). The articles were also classified with regard to the type of evaluation. Studies that employed molecular tests, such as ELISA, RIA, chromatography or enzyme activity for the identification and quantification of genes, messenger RNA and the expression of proteins related to lipolysis/lipogenesis received a score of 2, whereas those that simply performed exclusive serum analyses of non-esterified fatty acids (NEFA) or other plasma analyses received a score of 1 . Thus, the maximal score a study could receive was 13 points. 


\section{RESULTS}

The search in the PubMed database yielded 89 articles, three of which were selected for the review (Table 1). The Scopus database yielded 95 articles, only seven of which were selected for the review. However, three had been selected in the previous search. The search of the ISI Web of Science database yielded 97 articles, but only one additional study was selected for the review. The total number of articles selected for the review and displayed was higher than the total number of articles reviewed due to the fact that the same articles appeared in the searches with different keywords. The search of the Science Direct database yielded five articles that had been found in previous searches. A total of eight papers were selected based on the eligibility criteria. Table 2 displays a summary of the methodology of the studies and the main results obtained. Table 3 displays the scores of the studies based on the proposed assessment methodology. Among the eight papers selected, six $(75 \%)$ involved pigs as the experimental model, one involved fish and one involved mice. Six studies were carried out with 20 or more animals while only eight animals were used on two other studies.

Table 1 - Detailed results of search for each keyword.

\begin{tabular}{|c|c|c|c|c|c|c|c|c|c|c|}
\hline Databases & Search & $\begin{array}{l}\mathrm{R} \text { and } \\
\mathrm{LG}\end{array}$ & $\begin{array}{l}\mathrm{R} \text { and } \\
\mathrm{LP}\end{array}$ & $\begin{array}{l}\mathrm{R} \text { and } \mathrm{LG} \\
\text { and LP }\end{array}$ & $\begin{array}{l}\mathrm{R} \text { and } \\
\mathrm{FA}\end{array}$ & $\begin{array}{l}\mathrm{R} \text { and } \mathrm{LG} \\
\text { and FA }\end{array}$ & $\begin{array}{l}\mathrm{R} \text { and } \mathrm{LP} \\
\text { and FA }\end{array}$ & $\begin{array}{c}\mathrm{R} \text { and } \mathrm{LG} \\
\text { and } \mathrm{LP} \text { and } \\
\mathrm{FA}\end{array}$ & $\begin{array}{l}\mathrm{R} \text { and } \\
\mathrm{AT}\end{array}$ & Total $^{\mathrm{a}}$ \\
\hline \multirow{3}{*}{ PubMed } & $\begin{array}{l}\text { Number of papers } \\
\text { retrieved }\end{array}$ & 5 & 10 & 5 & 14 & 4 & 6 & 4 & 41 & 89 \\
\hline & $\begin{array}{l}\text { Papers selected } \\
\text { for review }\end{array}$ & 0 & 2 & 0 & 0 & 0 & 0 & 0 & 1 & 3 \\
\hline & $\begin{array}{l}\text { Found in previous } \\
\text { search }\end{array}$ & - & 0 & 0 & 0 & 0 & 0 & 0 & 0 & 0 \\
\hline \multirow{3}{*}{ Scopus } & $\begin{array}{l}\text { Number of papers } \\
\text { retrieved }\end{array}$ & 6 & 12 & 5 & 16 & 4 & 7 & 4 & 41 & 95 \\
\hline & $\begin{array}{l}\text { Papers selected } \\
\text { for review }\end{array}$ & 1 & 2 & 0 & 0 & 0 & 1 & 0 & 3 & 7 \\
\hline & $\begin{array}{l}\text { Found in previous } \\
\text { search }\end{array}$ & 0 & 1 & 0 & 0 & 0 & 1 & 0 & 2 & 4 \\
\hline \multirow{3}{*}{$\begin{array}{l}\text { ISI Web } \\
\text { of Science }\end{array}$} & $\begin{array}{l}\text { Number of papers } \\
\text { retrieved }\end{array}$ & 9 & 11 & 7 & 16 & 5 & 4 & 4 & 41 & 97 \\
\hline & $\begin{array}{l}\text { Papers selected } \\
\text { for review }\end{array}$ & 4 & 4 & 2 & 2 & 1 & 1 & 0 & 1 & 15 \\
\hline & $\begin{array}{l}\text { Found in previous } \\
\text { search }\end{array}$ & 3 & 4 & 2 & 1 & 1 & 1 & 0 & 1 & 13 \\
\hline \multirow{3}{*}{$\begin{array}{l}\text { Science } \\
\text { Direct }\end{array}$} & $\begin{array}{l}\text { Number of papers } \\
\text { retrieved }\end{array}$ & 0 & 1 & 0 & 1 & 0 & 1 & 0 & 2 & 5 \\
\hline & $\begin{array}{l}\text { Papers selected } \\
\text { for review }\end{array}$ & 0 & 1 & 0 & 1 & 0 & 1 & 0 & 2 & 5 \\
\hline & $\begin{array}{l}\text { Found in previous } \\
\text { search }\end{array}$ & 0 & 1 & 0 & 1 & 0 & 1 & 0 & 2 & 5 \\
\hline $\begin{array}{l}\text { Overall } \\
\text { Total }\end{array}$ & & & & & & & & & \multicolumn{2}{|c|}{8 papers } \\
\hline
\end{tabular}

$\mathrm{R}=$ Ractopamine; $\mathrm{LG}=$ Lipogenesis; $\mathrm{LP}=$ Lipolysis; FA = Fatty acid; AT = Adipose tissue

${ }^{\text {a }}$ Total number of articles selected for review may be larger than the total number of articles used due to the fact that the same article appeared in searches with different keywords 
Table 2 - Results of papers selected (in vivo studies on effect of ractopamine at promoting lipolysis or lipogenesis).

\begin{tabular}{|c|c|c|c|c|c|c|c|c|}
\hline & $\begin{array}{c}\text { Mills } \\
\text { et al. } 1990\end{array}$ & $\begin{array}{c}\text { Dunshea } \\
\text { and King } \\
1994\end{array}$ & $\begin{array}{c}\text { Liu et al. } \\
1994\end{array}$ & $\begin{array}{l}\text { Dunshea and } \\
\text { King } 1995\end{array}$ & $\begin{array}{c}\text { Dunshea } \\
\text { et al. } 1998\end{array}$ & $\begin{array}{l}\text { Vandenberg } \\
\text { et al. } 1998\end{array}$ & $\begin{array}{l}\text { Page et al. } \\
\quad 2004\end{array}$ & $\begin{array}{c}\text { Reiter } \\
\text { et al. } 2007\end{array}$ \\
\hline Species & Swine & Swine & Swine & Swine & Swine & Fish & Mice & Swine \\
\hline Sample n & 24 & 8 & 20 & 8 & 20 & 40 & 40 & 20 \\
\hline $\begin{array}{l}\text { Ractopamie } \\
\text { dose }\end{array}$ & $\begin{array}{c}0 \text { and } 20 \\
\text { ppm }\end{array}$ & $\begin{array}{c}0 \text { and } \\
20 \mathrm{ppm}\end{array}$ & $\begin{array}{c}0 \text { and } 20 \\
\text { ppm }\end{array}$ & $\begin{array}{c}0 \text { and } 20 \\
\text { ppm }\end{array}$ & $\begin{array}{c}0 \text { and } 20 \\
\text { ppm }\end{array}$ & $\begin{array}{c}0,5,10,20 \text { and } \\
40 \mathrm{ppm}\end{array}$ & $\begin{array}{l}200 \text { and } \\
800 \mathrm{ppm}\end{array}$ & $\begin{array}{c}0 \text { and } 20 \\
\text { ppm }\end{array}$ \\
\hline $\begin{array}{c}\text { Duration of } \\
\text { administration }\end{array}$ & Unclear & 24 days & $\begin{array}{c}1,8 \text { and } 24 \\
\text { days }\end{array}$ & 24 days & 24 days & 12 weeks & 21 days & 52 days \\
\hline $\begin{array}{c}\text { Determination } \\
\text { of LG, LP or } \\
\text { both }\end{array}$ & LG & LP & LG & LP & LG & LP & LP & Both \\
\hline $\begin{array}{l}\text { Method of } \\
\text { determination } \\
\text { of LG/LP } \\
\text { in vivo }\end{array}$ & $\begin{array}{l}\text { Activity } \\
\text { of FAS } \\
\text { and malic } \\
\text { enzyme }\end{array}$ & $\begin{array}{l}\text { Analysis } \\
\text { of } \\
\text { NEFAs }\end{array}$ & $\begin{array}{l}\text { Activity of } \\
\text { ACC and } \\
\text { malic } \\
\text { enzyme; } \\
\text { Extraction } \\
\text { and } \\
\text { determination } \\
\text { of mRNA } \\
\text { concentration } \\
\text { in ACC, } \\
\text { GLUT-1 and } \\
\text { GLUT-4. }\end{array}$ & $\begin{array}{l}\text { Concentrati } \\
\text { on of } \\
\text { plasma } \\
\text { NEFAs. }\end{array}$ & $\begin{array}{l}\text { Infusion and } \\
\text { incorporation } \\
\text { of }\left[\mathrm{U}^{-1}{ }^{4} \mathrm{C}\right] \\
\text { glucose in } \\
\text { adipose } \\
\text { tissue. }\end{array}$ & $\begin{array}{l}\text { Concentration of } \\
\text { NEFAs. }\end{array}$ & $\begin{array}{c}\text { Assay of } \\
\text { apoptosis in } \\
\text { adipose tissue } \\
\text { through } \\
\text { analysis of } \\
\text { DNA } \\
\text { fragments } \\
\text { characteristic } \\
\text { of occurrence } \\
\text { of apoptosis. }\end{array}$ & $\begin{array}{c}\text { Expression of } \\
\text { genes related } \\
\text { with } \\
\text { anabolism } \\
\text { (FAS, } \\
\text { GLUT-4, } \\
\text { SREBP-1) } \\
\text { and lipid } \\
\text { catabolism } \\
\text { (CPT-1). }\end{array}$ \\
\hline Main results & $\begin{array}{l}\text { Reduction } \\
\text { in activity } \\
\text { of malic } \\
\text { enzyme } \\
\text { with use of } \\
\text { ractopamine }\end{array}$ & $\begin{array}{l}\text { Did not } \\
\text { alter } \\
\text { plasma } \\
\text { concent } \\
\text { ration of } \\
\text { NEFAs }\end{array}$ & $\begin{array}{c}\text { Ractopamine } \\
\text { did not affect } \\
\text { activity of } \\
\text { ACC or malic } \\
\text { enzyme; } \\
\text { concentrations } \\
\text { of mRNA } \\
\text { were } \\
\text { unaltered in } \\
\text { ACC, } \\
\text { GLUT-1 and } \\
\text { GLUT- } 4 \text {. }\end{array}$ & $\begin{array}{l}\text { Ractopamine } \\
\text { did not affect } \\
\text { concentrations } \\
\text { of NEFAs. }\end{array}$ & $\begin{array}{l}\text { Ractopamine } \\
\text { did not affect } \\
\text { LG. }\end{array}$ & $\begin{array}{l}\text { Increase in plasma } \\
\text { concentrations of } \\
\text { NEFAS after } 4 \\
\text { weeks with doses } \\
\text { of } 5,10 \text { and } 20 \\
\text { ppm and after } 8 \\
\text { weeks with dose } \\
\text { of } 20 \text { ppm. }\end{array}$ & $\begin{array}{l}\text { Increase in } \\
\text { DNA } \\
\text { fragmentation } \\
\text { in tissues } \\
\text { (epididymis } \\
\text { /parametrial) } \\
\text { of animals } \\
\text { having } \\
\text { received } 800 \\
\text { ppm of } \\
\text { ractopamine. }\end{array}$ & $\begin{array}{c}\text { Ractopamine } \\
\text { reduced } \\
\text { concentration } \\
\text { of mRNA in } \\
\text { FAS, GLUT- } \\
4, \text { SREBP-1; } \\
\text { did not alter } \\
\text { concentration } \\
\text { of mRNA in } \\
\text { CPT-1. }\end{array}$ \\
\hline
\end{tabular}

LG = lipogenesis, LP = lipolysis, FAS = fatty acid synthetase, NEFA = non-esterified fatty acid, SREBP-1 = Sterol regulatory element-binding protein 1, CPT $-1=$ Carnitine palmitoyltransferase $1, \mathrm{ACC}=$ Acetyl-CoA carboxylase

Table 3 - Scores achieved by each article according to the criteria evaluated.

\begin{tabular}{|c|c|c|c|c|c|c|c|c|}
\hline $\begin{array}{c}\text { Evaluation } \\
\text { criteria }\end{array}$ & $\begin{array}{l}\text { Mills et } \\
\text { al. } 1990\end{array}$ & $\begin{array}{c}\text { Dunshea and } \\
\text { King } 1994\end{array}$ & $\begin{array}{c}\text { Liu et al. } \\
1994\end{array}$ & $\begin{array}{c}\text { Dunshea and } \\
\text { King } 1995\end{array}$ & $\begin{array}{l}\text { Dunshea et } \\
\text { al. } 1998\end{array}$ & $\begin{array}{c}\text { Vandenberg } \\
\text { et al. } 1998\end{array}$ & $\begin{array}{l}\text { Page et } \\
\text { al. } 2003\end{array}$ & $\begin{array}{l}\text { Reiter et } \\
\text { al. } 2007\end{array}$ \\
\hline Randomization & 2 & 2 & 1 & 2 & 1 & 2 & 1 & 2 \\
\hline Blind evaluation & 1 & 1 & 1 & 1 & 1 & 1 & 1 & 1 \\
\hline Control group & 2 & 2 & 2 & 2 & 2 & 2 & 2 & 2 \\
\hline Sample size & 3 & 1 & 2 & 1 & 2 & 3 & 3 & 2 \\
\hline $\begin{array}{l}\text { Determination of } \\
\text { LG, LP or both }\end{array}$ & 1 & 1 & 1 & 1 & 1 & 1 & 1 & 2 \\
\hline $\begin{array}{c}\text { Type of evaluation } \\
\text { LG/LP in vivo }\end{array}$ & 2 & 1 & 2 & 1 & 2 & 1 & 2 & 2 \\
\hline Total & 11 & 8 & 9 & 8 & 9 & 10 & 10 & 11 \\
\hline
\end{tabular}

The doses of ractopamine administered to the animals were predominantly from 0 to $20 \mathrm{ppm}$. Comparing to other species, Vandenberg et al. (1998) analyzed doses of $0,5,10,20$ and $40 \mathrm{ppm}$ in the rainbow trout and Page et al. (2004) analyzed high doses of 200 and $800 \mathrm{ppm}$ in mice.
The ractopamine administration period varied between studies. Four studies $(50 \%)$ analyzed a period of 24 days. Mills et al. (1990) did not analyze a particular period of time, but rather the administration of ractopamine at the final $41 \mathrm{~kg}$ (pre-slaughter), beginning with $59 \mathrm{~kg}$, and 
therefore the administration period was classified as unclear. Vandenberg et al. (1998) and Reiter et al. (2007) worked with longer administration periods - 12 weeks (84 days) and 52 days, respectively.

Regarding the determination of the occurrence of lipolysis or lipogenesis, four papers only determined the occurrence of lipolysis or lack thereof, three papers determined the occurrence of lipogenesis and only one paper determined both effects. For the determination of the occurrence of lipolysis, lipogenesis or both variables, different methodologies were employed, ranging from plasma analyses of NEFAs or adipose tissue assessment techniques, such as enzyme activity and molecular tests, such as Dot-Blot hybridization, PCR and Northern Blotting for the analysis of RNA/DNA and genes related to these occurrences. None of the studies selected for this systematic review specified whether blinded evaluations were performed.

Among the three studies that only quantified lipogenesis, two (Liu et al. 1994; Mills et al. 1990) carried out the trials to determine enzyme activity. In the first, the authors tested FAS and malic enzyme. In the second, the authors tested ACC and malic enzyme and quantified the expression of mRNA of ACC, Glut-1 and Glut-4. Mills et al. (1990) reported a reduction in the malic enzyme activity, whereas Liu et al. (1994) did not observe this effect. Liu et al. (1994) found no alterations in the concentrations of mRNA of ACC or GLUT-1 and GLUT-4. Dunshea et al. (1998) found no effect of ractopamine on lipogenesis. Reiter et al. (2007) quantified the expression of mRNA in both lipolytic and lipogenic enzymes and found a reduction in the concentration of mRNA in the enzymes related to lipogenesis (FAS and SREBP1) as well as the glucose transporter GLUT-4 in adipocytes.

Four studies only quantified lipolysis. Three of these analyzed this variable through the quantification of NEFAs. One work (Page et al. 2004) quantified the presence of DNA fragments related to the occurrence of apoptosis and was therefore classified as having determined lipolysis. Vandenberg et al. (1998) provided ractopamine in different doses to specimens of trout for 12 weeks and found an increase in the serum levels of NEFAs after four weeks when using 5, 10 and 20 ppm and after eight weeks when using $20 \mathrm{ppm}$. Page et al. (2004) detected an increase in DNA fragments related to the apoptosis of adipocytes in mice having received $800 \mathrm{ppm}$ of ractopamine in the diet.

\section{DISCUSSION}

The present review employed explicit methods to carry out a detailed bibliographic study and allowed a clearer visualization of the results. The decision was made to use four international databases of considerable scientific importance in order to ensure the broad scope of the search. It should be pointed out that the ISI Web of Science was the only database that yielded all the papers selected for the review due to the fact that its content encompassed the articles in both the fields of biomedicine and livestock farming.

The criteria used for the construction of this review were defined with the aim of assessing the effects of the administration of ractopamine on lipogenesis and/or lipolysis as well as the methodological quality of the studies selected. The limitations of the study should be addressed. Some of the articles published on this subject were not retrieved due to the fact that the title did not contain the descriptors employed or the keywords indexed. However, the authors made considerable effort to avoid the exclusion of any article for this review. It should also be mentioned that the criteria regarding the methodological quality of the assessment were defined based on the experience of the authors and were therefore not definitive. It was believed that molecular and enzyme activity analyses were more reliable when associated to phenotype observations than the serum analyses, which could be influenced by other variables, such as feeding time prior to collection or stress during the vein perforation. Molecular analyses provide a broader view of the action mechanism due to the quantification of both gene expression and products (mRNA and proteins).

For the present review, all the studies found based on the search with the keywords were used and no restrictions were placed with regard to the species due to the small number of articles analyzing the effect of ractopamine in vivo. Therefore, regardless of species, the determination of the occurrence of lipolysis or lipogenesis in vivo as a consequence of the administration of ractopamine was of fundamental importance, as a large number of studies employed in vitro tests (Liu et al. 1989; Peterla et al. 1990; Dunshea et al. 1993; Mills et 
al. 2003a). Such studies were valid from the scientific standpoint for demonstrating a biological event, but could not be directly extrapolated to a complex organism due to the large number of interactions with other metabolic pathways (López-Carlos et al. 2011). Mersmann and Shparber (1993) found isolated adipocytes to be smaller than in vivo adipocytes, but the quantification of lipolysis was similar. Thus, there were innumerous exceptions to this rule.

One of the effects of the administration of ractopamine is a reduction in the deposition of fat in the carcass (Carr et al. 2009). The efficiency of ractopamine regarding the reduction in adipose tissue may be more related to the activity of this substance in blocking lipogenesis than stimulating lipolysis (Mills et al. 2003b). In the pigs, this BAA has been found to reduce the sensitivity of adipocytes to insulin, thereby proving capable of inhibiting lipogenesis (Liu and Mills 1990; Mills 2002; Mills et al. 1990).

The anti-lipogenic effect of ractopamine was reported in two studies selected for this review, both of which involved the pigs, whereas another two studies did not observe this effect. Mills et al. (1990) reported a reduction in the activity of malic enzyme, which is an important lipogenic enzyme that catalyzes the oxidative decarboxylation of malate into pyruvate. Reiter et al. (2007) reported a reduction in the gene expression of fatty acid synthase (FAS) - the main enzyme related to the synthesis of fatty acids and, consequently, lipogenesis - in SREBP-1, which is a transcription factor for lipogenic enzymes and cholesterol esters (Shimano et al. 1999), as well as a reduction in the expression of the glucose transporter GLUT-4, which impedes excess glucose from being capture by adipocytes, allowing it to be redirected for protein synthesis in the muscles. Liu et al. (1994) assessed the activity and expression of mRNA in ACC and found no alterations, which could be specifically related to the enzyme quantified, as other authors assessed other key enzymes in the lipogenesis process that were negatively affected by ractopamine, such as FAS (Reiter et al. 2007).

In vitro studies with the pigs also demonstrated that BAAs stimulated the production of cyclic adenosine monophosphate, which activates kinases, which, in turn, phosphorylate and activate the regulating enzyme of lipolysis - hormonesensitive lipase (Coutinho et al. 1989; Mills et al. 2003b; Moody et al. 2000; Spurlock et al. 1993). Thus, an increase in NEFAs in the blood would be expected. In the 1980s, a number of authors believed that BAAs had the property of stimulating the lipolysis in adipose tissue, catalyzed by the hormone-sensitive lipase and releasing free fatty acids into the blood stream (Baker et al. 1984; Jones et al. 1985; Ricks et al. 1984). However, the present review found that the authors who worked with the determination of lipolysis in the pigs through the quantification of serum NEFAs did not find any increase in these elements (Dunshea and King 1994; Dunshea and King, 1995), thereby indicating that lipolysis might not be the preponderant factor in the reduction in the amount of adipose tissue deposited in the carcass of pigs. On the other hand, Vandenberg et al. (1998) reported an increase in serum concentrations of NEFAs in the rainbow trout. The authors observed that the effect of desensitization of $\beta$-adrenergic receptors was retarded in the fish. The lipolytic effect was less than expected, but, according to the authors, juvenile specimens of the trout were relatively insensitive to the effect of the acute stimulation of lipolysis by ractopamine.

Page et al. (2004) reported an increase in the occurrence of apoptosis of adipocytes in mice fed with a diet supplemented with $800 \mathrm{ppm}$ of ractopamine. This could have been due to the dose, which was much higher than that used in other species. Dunshea and King (1995) suggested that ractopamine at doses of 0 and $20 \mathrm{ppm}$ did not stimulate fat mobilization or lipolysis in the pigs or, if it occurred, the effect disappeared after three days.

This disagreement in results between the species could be due to the different expression of $\beta$ adrenergic receptors. McNell and Mersmann (1999) found three subtypes of $\beta$-adrenergic receptors in the white adipose tissue of the pigs. The authors quantified the production of mRNA for these three receptor subtypes and found that $73 \%$ were subtype $\beta_{1}, 20 \%$ were subtype $\beta_{2}$ and only $7 \%$ were subtype $\beta_{3}$. It was also found that there was $32 \%$ higher concentration of $\beta_{3}$ receptors over $\beta_{1}$ in the adipose tissue in rats, unlike what was found in the pigs. This different distribution of receptors could explain the observation by Liu et al. (1989) that the effects of ractopamine on adipocytes were more accentuated in the rats than pigs. Likewise, Hollenga and Zaagsma (1989) reported that $\beta_{3}$ receptors were predominant in the rodents and measured the majority of lipolytic effects in the species. Mills et al. (2003b) reported 
that previous studies suggest that ractopamine likely had greater affinity for $\beta_{2}$ receptors, which were not linked to a lipolytic response. However, this receptor acted on the lipolytic metabolism pathway in the pigs and that ractopamine could activate this pathway in some cases. Nonetheless, due to the fact that it was present in greater quantity, it is possible that the $\beta_{1}$ receptor is the preferential target of BAAs in pigs. Indeed, studies have demonstrated that ractopamine-induced lipolysis occurs little in swine adipocytes.

Besides the issue of the distribution receptors, an event that may also be questioned is the downregulation of receptors (Liu et al. 1994; Mills et al. 1990), which is directly linked to the dose of the activator used. Spurlock et al. (1994) found that ractopamine reduced the density of $\beta$-adrenergic receptors in the adipose tissue in the pigs by approximately $50 \%$.

The doses of ractopamine that are normally used depend on the species under study. As shown in the articles analyzed in the present review, those that employed the pig model administered doses between 0 and $20 \mathrm{mg} / \mathrm{kg}$. Ferreira et al. (2011) demonstrated that a dose of $5 \mathrm{ppm}$ of ractopamine in the animals with a high genetic potential for the synthesis of muscle tissue was sufficient to achieve benefits in the performance and enhanced the characteristics of the carcass, including a reduction in the lipid deposition, whereas higher doses did not offer additional effects. Therefore, the definition of the ractopamine dosage for the pigs depended mainly on the lineage used (Schinckel et al. 2002). However, one should take into consideration that the breeding of the animals derived from genetic lineages with a greater tendency toward the deposition of large amounts of adipose tissue might require larger doses of ractopamine.

As ractopamine is a BAA that redirects the energy of the diet toward protein synthesis, the fattening period is the most adequate period for this supplementation, as it is in this period that greater lipid deposition occurs in the carcass. The duration of administration should also take into account the effects of desensitization, which occur earlier in pigs than in fish (Vandenberg et al. 1998). Studies established either constant doses for 21 to 28 days (Scramlin et al. 2008) or increasing doses beginning on Day 14 in a total of 28 days (See et al. 2004).

The ISI Web of Science was the most efficient among the databases searched in the present review for the articles related to the use of ractopamine as a carcass modifier additive. The lipogenesis/lipolysis relationship caused by the BAAs, especially ractopamine, is influenced by the subtypes of receptors among different species. In the pigs, which was the main study model found in the literature, there was evidence that ractopamine reduced the amount of lipids in the carcass through a greater inhibition of lipogenesis than an increase in lipolysis. Further studies should be carried out involving other species of commercial interest in order to gain a better understanding of the action mechanism of these substances.

\section{ACKNOWLEDGEMENTS}

This work was supported in part by FAPEMIG (Research Support Foundation of the State of Minas Gerais), CNPq (National Council for Scientific and Technological Development), CAPES (Coordination of Improvement of Higher Education Personnel), Veterinary Medicine Graduate Program and Graduate Directory of the Federal University of Lavras, Brazil. One of the authors (LJP) acknowledges the scholarship from $\mathrm{CNPq}$ during the execution of this study.

\section{REFERENCES}

Baker PK, Dalrymple RH, Ingle DL, Ricks CA. Use of a $\beta$-adrenergic agonist to alter muscle and fat deposition in lambs. J Anim Sci. 1984; 59:1256-61.

Carr SN, Hamilton DN, Miller KD, Schroeder AL, Fernández-Dueñas D, Killefer J, et al. The effect of ractopamine hydrochloride (Paylean ${ }^{\circledR}$ ) on lean carcass yields and pork quality characteristics of heavy pigs fed normal and amino acid fortified diets. Meat Sci. 2009; 81:533-39.

Coutinho LL, Cameron JK, Romsos DR, Merkel RA, Bergen WG. Isoproterenol, ractopamine and clenbuterol stimulate lipolysis in porcine adipocytes with different affinity and maximal rate. J Anim Sci. 1989; 67:100.

Dunshea FR, King RH, Campbell RG, Sainz RD, Kim YS. Interrelationships between sex and ractopamine on protein and lipid deposition in rapidly growing pigs. J Anim Sci. 1993; 71:2919-30.

Dunshea FR, King RH. Temporal response of plasma metabolites to ractoparnine treatment in the growing pig. Aust J Agric Res. 1994; 45:1683-92. 
Dunshea FR, King RH. Responses to homeostatic signals in ractopamine-treated pigs. Br J Nutr 1995; 73:809-818.

Dunshea FR, Leury BJ, Tilbrook AJ, King RH. Ractopamine increases glucose turnover without affecting lipogenesis in the pig. Aust J Agric Res 1998; 49:1147-52.

Ferreira MSS, Sousa RV, Silva VO, Zangerônimo MG, Amaral NO. Cloridrato de ractopamina em dietas para suínos em terminação. Acta Sci Anim Sci. 2011; 33:25-32.

Gonzalez JM, Johnson SE, Stelzleni AM, Thrift TA, Savell JD, Warnock TM, et al. Effect of ractopamine- $\mathrm{HCl}$ supplementation for 28 days on carcass characteristics, muscle fiber morphometrics, and whole muscle yields of six distinct muscles of the loin and round. Meat Sci 2010; 85:379-84.

Gunawan AM, Richert BT, Schinckel AP, Grant AL, Gerrard DE. Ractopamine induces differential gene expression in porcine skeletal muscles. J Anim Sci 2007;85:2115-24

Hausman DB, Martin RJ, Veenhuizen EL, Anderson DB. Effect of ractopamine on insulin sensitivity and response of isolated rat adipocytes. J Anim Sci 1989;67:1455-64.

Hejnfelt A, Angelidaki I. Anaerobic digestion of slaughterhouse by-products. Biomass Bioenergy 2009;33:1046-54.

Hollenga C, Zaagsma J. Direct evidence for the atypical nature of functional beta- adrenoceptors in rat adipocytes. Br J Pharmacol 1989;98:1420-24.

Jones RW, Easter R, McKeith RH. Effect of the $\beta$ adrenergic cimaterol (CL263.780) on the growth and carcass characteristics of finishing swine. J Anim Sci 1985;61:905-13.

Kim H, Della-Fera MA, Hausman DB, Baile CA. Effect of clenbuterol on apoptosis, adipogenesis, and lipolysis in adipocytes. J Physiol Biochem 2010;66:197-203.

Liu CY, Boyer JL, Mills SE. Acute effects of betaadrenergic agonists on porcine adipocyte metabolism in vitro. J Anim Sci 1989;67:2930-36.

Liu CY, Mills SE. Decreased insulin binding to porcine adipocytes in vitro by beta-adrenergic agonists. J Anim Sci 1990;68:1603-08.

Liu CY, Grant AL, Kim KH, Ji SQ, Hancock DL, Anderson DB, Mills SE. Limitations of ractopamine to affect adipose tissue metabolism in swine. J Anim Science 1994;72:62-67.

López-Carlos MA, Ramírez RG, Aguilera-Soto JI, Aréchiga CF, Méndez-Llorente F, Rodríguez H, Silva JM. Effect of ractopamine hydrochloride and zilpaterol hydrochloride on growth, diet digestibility, intake and carcass characteristics of feedlot lambs. Livest Sci 2011;131:23-30.
McNeel RL, Mersmann HJ. Distribution and quantification of beta1-, beta2-, and beta3-adrenergic receptor subtype transcripts in porcine tissues. J Anim Sci 1999;77:611-21.

Mersmann HJ, Shparber A. Is the lipolytic response in porcine adipose tissue slices equivalent to the lipolytic response in isolated adipocytes? Int $\mathbf{J}$ Biochem 1993;25:1673-79.

Mills SE. Biological basis of the ractopamine response. J Anim Sci 2002;80(Suppl 2):E28-32.

Mills SE, Liu CY. Sensitivity of lipolysis and lipogenesis to dibutyryl-cAMP and beta-adrenergic agonists in swine adipocytes in vitro. J Anim Sci 1990a;68:1017-23.

Mills SE, Liu CY, Gu Y, Schinckel AP. Effects of ractopamine on adipose tissue metabolism and insulin binding in finishing hogs. Interaction with genotype and slaughter weight. Domest Anim Endocrin 1990b; 7:251-64.

Mills SE, Kissel J, Bidwell CA, Smith DJ. Stereoselectivity of porcine beta-adrenergic receptors for ractopamine stereoisomers. J Anim Sci. 2003; 81:122-29.

Mills SE, Spurlock ME, Smith DJ. $\beta$-Adrenergic receptor subtypes that mediate ractopamine stimulation of lipolysis. J Anim Sci. 2003; 81:662-68.

Mimbs KJ, Pringle TD, Azain MJ, Meers SA, Armstrong TA. Effects of ractopamine on performance and composition of pigs phenotypically sorted into fat and lean groups. J Anim Sci. 2005; 83:1361-69.

Mitchell AD. Effect of ractopamine on growth and body composition of pigs during compensatory growth. Anim. 2009; 3:173-80.

Moody DE, Hancok DL, Anderson DB. Phenethanolamine repartitioning agents. In: Mello JPFD, eds. Farm animal metabolism and nutrition. New York, NY: CABI Publishing; 2000. p. 65-95.

Page KA, Hartzell DL, Li C, Westby AL, Della-Fera MA, Azain MJ, Pringle TD, et al. $\beta$-Adrenergic receptor agonists increase apoptosis of adipose tissue in mice. Domest Anim Endocrin. 2004; 26:23-31.

Peterla TA, Scanes CG. Effect of beta-adrenergic agonists on lipolysis and lipogenesis by porcine adipose tissue in vitro. J Anim Sci. 1990; 68:1024-29.

Petersen ST. The potential ability of swine nutrition to influence environmental factors positively. J Anim Sci. 2010; 88(electronic suppl):E95-101.

Reiter SS, Halsey CHC, Stronach BM, Bartosh JL, Owsley WF, Bergen WG. Lipid metabolism related gene-expression profiling in liver, skeletal muscle and adipose tissue in crossbred Duroc and Pietrain Pigs. Comp Biochem Phys D. 2007; 2:200-206. 
Ricks CA, Dalrymple RH, Baker PK, Ingle DL. Use of $\beta$ - agonist to alter fat and muscle deposition in steers. J Anim Sci. 1984; 59:1247-55.

Schinckel AP, Richert BT, Herr CT. Variation in the response of multiple genetic populations of pigs to ractopamine. J Anim Sci. 2002; 80:E85-E89.

Scramlin SM, Carr SN, Parks CW, Fernandez-Dueñas DM, Leick CM, Mckeith FK, et al. Effect of ractopamine level, gender, and duration of ractopamine on belly and bacon quality traits. Meat Sci. 2008; 80:1218-21.

See MT, Armstrong TA, Weldon WC. Effect of a ractopamine feeding program on growth performance and carcass composition in finishing pigs. J Anim Sci. 2004; 82: 2474-80.

Shimano H, Yahagi N, Amemiya-Kudo M, Hasty AH, Osuga J, Tamura Y, et al. Sterol Regulatory Elementbinding Protein-1 as a Key Transcription Factor for Nutritional Induction of Lipogenic Enzyme Genes. $J$ Biol Chem1. 1999; 274:35832-39.

Spurlock ME, Cusumano JC, Mills SE. The affinity of ractopamine, clenbuterol, and 1-644,969 for the betaadrenergic receptor population in porcine adipose tissue and skeletal muscle membrane. J Anim Sci. 1993; 71:2061-65.
Spurlock ME, Cusumano JC, Ji SQ, Anderson DB, Smith 2nd CK. Hancock DL, Mills SE. The effect of ractopamina on $\beta$-adrenoceptor density and affinity in porcine adipose and skeletal muscle tissue. J Anim Sci. 1994; 72:75-80.

Uttaro BE, Ball RO, Dick P, Rae W, Vessie G, Jeremiah LE. Effect of ractopamine and sex on growth, carcass characteristics, processing yield, and meat quality characteristics of crossbred swine. $J$ Anim Sci. 1993; 71:2439-49.

Vandenberg GW, Leatherland JF, Moccia RD. The effects of the beta-agonist ractopamine on growth hormone and intermediary metabolite concentrations in rainbow trout, Oncorhyncus mykiss (Walbaum). Aquac Res. 1998; 29:79-87.
Received: July 07, 2011; Revised: October 11, 2011; Accepted: August 09, 2012. 